\title{
Penerapan Metode ACP untuk Optimasi Physical Tuning Antena Sektoral pada Jaringan 4G LTE di Kota Purwokerto
}

\author{
AFATAH PURNAMA, EKA SETIA NUGRAHA, MUNTAQO ALFIN AMANAF
}

Program Studi D3 Teknik Telekomunikasi

Institut Teknologi Telkom Purwokerto, Indonesia

Email : purnamaafatah@gmail.com

Received 22 Juli 2019 | Revised 14 September 2019 | Accepted 7 November 2019

\begin{abstract}
ABSTRAK
Kualitas jaringan $4 G$ (LTE) yang masih tidak stabil sehingga menyebabkan bad coverage. Untuk meningkatkan kualitas jarigan $4 G$ (LTE) dapat dilakukan dengan optimasi physical tuning antena sektoral. Physical tuning antena sektoral meliputi perubahan tinggi antena, azimuth dan tilting antena. Pada penelitian ini dilakukan optimasi physical tuning antena sektoral menggunakan metode Automatic Cell Planning (ACP) untuk memenuhi kebutuhan coverage di daerah Purwokerto Barat dan Purwokerto Utara. Perolehan persentase coverage site existing belum memenuhi standar KPI Operator untuk RSRP sebesar 78,491\% $\geq$ (100) $d B m$ dan CINR sebesar 65,698\% $\geq(0) d B$. Hasil optimasi physical tuninng antena sektoral menggunakan metode ACP sudah memenuhi standar KPI Operator untuk RSRP sebesar $90,037 \% \geq(100) \mathrm{dBm}$ dan CINR sebesar $94,868 \% \geq(0) d B$.
\end{abstract}

Kata kunci: LTE, optimasi, physical tuning, Automatic Cell Planning, Atoll

\begin{abstract}
The quality of the $4 G$ (LTE) network is still unstable, causing bad coverage. To improve the quality of $4 G$ network ( $L T E)$ can be done by sectoral antenna tuning optimization. Physical tuning of sectoral antennas includes changes in antenna height, azimuth and tilting antenna. In this study a sectoral antenna tuning physical optimization was carried out using the Automatic Cell Planning (ACP) method to meet coverage needs in West Purwokerto and North Purwokerto areas. The percentage of existing coverage sites has not met the KPI Operator standard for RSRP of $78.491 \% 100$ (100) dBm and CINR of $65.669 \% \geq(0) d B$. The results of sectoral antenna tuning optimization using the $A C P$ method have met the KPI Operator standard for RSRP of $90.037 \% \geq(100) \mathrm{dBm}$ and CINR of $94.868 \% \geq(0) d B$.
\end{abstract}

Keywords: LTE, optimization, physical tuning, Automatic Cell Planning, Atoll 
Penerapan Metode ACP untuk Optimasi Physical Tuning Antena Sektoral pada Jaringan 4G LTE di Kota Purwokerto

\section{PENDAHULUAN}

Perkembangan teknologi terutama di bidang telekomunikasi yang semakin pesat berbanding terbalik dengan kondisi kenyataan di lapangan yaitu penerapan teknologi seluler di Purwokerto untuk memenuhi kebutuhan masyarakat masih terkendala disebabkan oleh jaringan yang masih tidak stabil sehingga menyebabkan bad coverage di beberapa titik. Titik yang temasuk dalam bad coverage berada di Kecamatan Purwokerto Barat dan Purwokerto Utara (Wibawa, 2019). Kepadatan penduduk di daerah Purwokerto cukup tinggi berjumlah 254.903 penduduk yang tersebar di empat Kecamatan yaitu Kecamatan Purwokerto Timur, Kecamatan Purwokerto Barat, Kecamatan Purwokerto Selatan dan Kecamatan Purwokerto Utara (Banyumas, 2018). Wilayah yang akan di optimasi jaringan LTE yaitu Kecamatan Purwokerto Barat dan Kecamatan Purwokerto Utara. Peminat jaringan 4G (LTE) dipastikan akan terus mengalami peningkatan karena jaringan 4G (LTE) menawarkan kecepatan data hingga 100 Mbps untuk download dan hingga 50 Mbps untuk upload. Oleh karena itu penyedia provider diharapkan mampu memberikan pelayanan jaringan yang maksimal untuk pengguna (Putra, dkk, 2017). Pada penelitian sebelumya yang dilakukan oleh Melinda $\mathrm{Br}$ Ginting (2017), dengan judul Optimasi Jaringan Coverage UMTS Dengan Azimuth dan Tilting Antena Sektoral di Sukoharjo Menggunakan Metode Automatic Cell Planning (ACP) dan Unautomatic Planning" yang melakukan optimasi untuk memaksimalkan coverage area dan meningkatkan kualitas jaringan UMTS di Sukoharjo. Optimasi dilakukan dengan cara mengubah azimuth dan tilting antena sektoral untuk meningkatkan kualitas jaringan UMTS. Metode optimasi menggunakan metode ACP dan Unautomatic Planning (Ginting, 2017).

Terdapat tiga metode optimasi yaitu Automatic Frequency Planning (AFP), Automatic Site Position (ASP) dan Automatic Cell Planning (ACP). Metode optimasi AFP dapat menentukan pita frekuensi dan nomor saluran secara otomatis ke sel sehingga gangguan jaringan dapat diminimalkan. Metode ASP dapat menentukan lokasi site baru sesuai dengan tujuan coverage area, orientasi lalu lintas jaringan dan berbasis populasi. Metode ACP memungkinkan perhitungan secara otomatis dari parameter optimasi untuk meningkatkan kualitas jaringan berdasarkan coverage dan capacity. Pada penelitian ini optimasi dilakukan dengan metode ACP pada jaringan LTE karena berdasarkan data site existing dengan frekuensi kerja yang digunakan yaitu $1800 \mathrm{MHz}$ hanya optimasi metode ACP yang dapat menghitung secara otomatis tuning parameter. Beberapa tuning yang dilakukan untuk mengoptimalkan jaringan LTE terhadap coverage area pancaran sinyal ialah mengalkulasi tinggi antena, azimuth dan tilting antena. Proses kalkulasi tersebut akan berpengaruh terhadap parameter RSRP dan CINR yang secara otomatis akan dikalkulasi berdasarkan coverage area dari seluruh lokasi site. Pada saat melakukan optimasi dengan metode ACP akan mengoptimalkan parameter optimasi untuk mencapai tujuan yang ditentukan. Tujuan ini digunakan sebagai dasar untuk search algorithm. Search algorithm yaitu algoritma yang berusaha untuk menemukan yang terbaik dari kombinasi parameter untuk mencapai tujuan optimasi yang ditentukan. Pada langkah terakhir, sorting algorithm menyediakan suatu rencana implementasi perubahan mana yang paling berguna dalam hal mengidealkan kualitas jaringan (Forsk, Atoll 3.3.0 Technical Reference Guide For Radio Network, 2015). Untuk mendapatkan kualitas sinyal berdasarkan kemampuan coverage-nya menggunakan prediksi pengukuran berdasarkan coverage by $C /(I+N)$ level dan effective signal analysis yang terdapat pada software Atoll. Dengan optimasi physical tuning antena dengan metode ACP arah pancar yang diberikan antena sektoral mengarah tepat ke seluruh site yang saling terhubung sehingga dapat meningkatkan kualitas distribusi sinyal untuk mencakup wilayah yang dioptimasi tersebut (Hikmaturokhman, dkk, 2014). 


\section{METODE PENELITIAN}

\subsection{Perancangan Sistem}

Dalam penelitian ini, optimasi physical tuning antena sektoral pada jaringan LTE menggunakan metode Automatic Cell Planning (ACP). Optimasi physical tuning antena sektoral dilakukan untuk meningkatkan kualitas jaringan LTE di wilayah Purwokerto Barat dan Purwokerto Timur. Penentuan target KPI Operator digunakan untuk mengetahui tingkat keberhasilan atau kegagalan hasil optimasi ACP. Target untuk RSRP yaitu $80 \% \geq(-100) \mathrm{dBm}$ dan untuk CINR 90\% $\geq(0) \mathrm{dB}$ (Telkomsel, 2016). Parameter yang diukur sebagai bahan perbandingan antara hasil simulasi site existing dengan hasil optimasi ACP adalah RSRP dan CINR yang dapat dilihat pada Gambar 1.
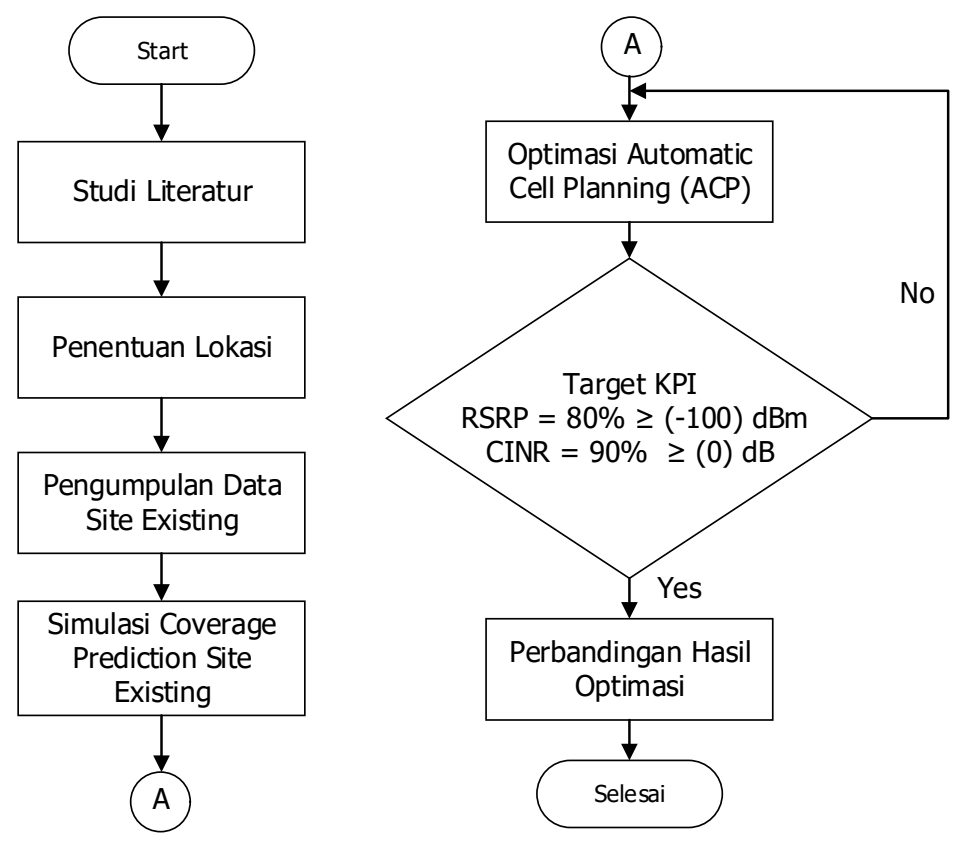

Gambar 1. Diagram Alir Penelitian

\subsection{Penentuan Wilayah Penelitian}

Optimasi ACP dilakukan di wilayah Kecamatan Purwokerto Barat dan Purwokerto Utara yang dikategorikan dalam wilayah sub-urban. Adapun data wilayah dan kependudukan yang didapatkan dari Badan Pusat Statistik Kabupaten Banyumas yang ditunjukkan pada Tabel 1.

Tabel 1. Data Wilayah Pengamatan (Banyumas, 2018)

\begin{tabular}{|c|c|c|c|}
\hline No & Kecamatan & Luas Wilayah $\mathbf{( k m}^{\mathbf{2}}$ ) & Jumlah Penduduk (Jiwa) \\
\hline 1 & Purwokerto Barat & 7,40 & 52.903 \\
\hline 2 & Purwokerto Utara & 9,01 & 66.011 \\
\hline \multicolumn{2}{|c}{ Total } & 16,41 & 118.914 \\
\hline
\end{tabular}

\subsection{Simulasi Site Existing}

Simulasi site existing merupakan simulasi berdasarkan perolehan data site existing oleh operator $\mathrm{X}$ yang berisi nama site, titik koordinat, tinggi antena, azimuth, dan tilting antena sektoral. Parameter tersebut yang akan dijadikan sebagai data acuan untuk simulasi site exsiting dengan optimasi ACP. 
Penerapan Metode ACP untuk Optimasi Physical Tuning Antena Sektoral pada Jaringan 4G LTE di Kota Purwokerto

1. Pemilihan Radio Akses Teknologi

Penggunaan frekuensi 4G LTE di Purwokerto mempunyai spesifikasi di $850 \mathrm{MHz}, 900 \mathrm{MHz}$, $1800 \mathrm{MHz}$ dan $2300 \mathrm{MHz}$ untuk beberapa operator yang ada di Purwokerto. Alokasi frekuensi $1800 \mathrm{MHz}$ digunakan oleh beberapa operator seluler di Indonesia seperti Telkomsel dan XL dengan bandwith 22,5 MHz, H3I dengan bandwidth $10 \mathrm{MHz}$ dan ISAT dengan bandwidth 20 $\mathrm{MHz}$. Pada penelitian ini radio akses teknologi menggunakan frekuensi $1800 \mathrm{MHz}$ dengan bandwidth $15 \mathrm{MHz}$. Spesifikasi frekuensi $1800 \mathrm{MHz}$ dapat ditunjukkan pada Tabel 2.

Tabel 2. Spesifikasi Frekuensi $1800 \mathrm{MHz}$ (Motorolla, 2011)

\begin{tabular}{|c|c|}
\hline Parameter & Informasi \\
\hline Bandwidth & $15 \mathrm{MHz}$ \\
\hline Duplexing Methode & FDD \\
\hline UL Start Frequency & $1710 \mathrm{MHz}$ \\
\hline DL Start Frequency & $1805 \mathrm{MHz}$ \\
\hline
\end{tabular}

\section{Import Data Atoll}

Import data Atoll berupa informasi data untuk simulasi berupa data clutter classes, clutter heights, altitude dan map. Data tersebut digunakan untuk menampilkan kondisi wilayah simulasi (Forsk, 2010).

3. Konfigurasi Antena

Pada penelitian ini antena yang digunakan untuk simulasi sesuai dengan frekuensi yang digunakan. Spesifikasi antena dapat ditunjukkan pada Tabel 3.

Tabel 3. Spesifikasi Antena (Huawei, 2013)

\begin{tabular}{|c|c|}
\hline Parameter & Informasi \\
\hline Frequency Range & $1710 \mathrm{MHz}-1990 \mathrm{MHz}$ \\
\hline Gain & $17 \mathrm{dBi}$ \\
\hline Horizontal3 dB beamwidth & $66^{\circ}$ \\
\hline Mechanical tilt & $0-12$ \\
\hline Electrical tilt & $0^{\circ}-16^{\circ}$ \\
\hline
\end{tabular}

\subsection{Simulasi Optimasi ACP}

Metode Automatic Cell Planning (ACP) akan secara otomatis menghitung tuning parameter yang dilakukan secara otomatis. Beberapa tuning yang dapat dilakukan untuk mengoptimalkan jaringan LTE terhadap coverage area pancaran sinyal ialah mengalkulasi tinggi antena, azimuth dan tilting antena. Proses kalkulasi tersebut akan berpengaruh terhadap parameter RSRP dan CINR yang secara otomatis akan dikalkulasi berdasarkan coverage area dari seluruh lokasi site. Prediksi kualitas Automatic Cell Planning (ACP) harus sama dengan prediksi coverage pada Atoll. Pada penelitian ini menggunakan prediksi Effective Signal Analysis (DL) pada prediksi di Atoll untuk menganalisis prediksi RSRP di Automatic Cell Planning (ACP) dan prediksi Coverage by $C /(I+N)$ Level (DL) pada prediksi di Atoll untuk menganalisis prediksi CINR di Automatic Cell Planning (ACP). Terdapat beberapa tab menu yang harus dikonfigurasi untuk melakukan optimasi metode Automatic Cell Planning (ACP) yaitu Optimisation, Objectives, Reconfiguration, dan Antenna (Forsk, 2010).

Pada saat melakukan optimasi dengan metode Automtic Cell Planning (ACP) akan mengoptimalkan parameter optimasi untuk mencapai tujuan yang ditentukan. Tujuan ini digunakan sebagai dasar untuk search algorithm. Search algorithm yaitu algoritma yang berusaha untuk menemukan yang terbaik dari kombinasi parameter untuk mencapai tujuan 
optimasi yang ditentukan. Pada langkah terakhir, sorting algorithm menyediakan suatu rencana implementasi perubahan mana yang paling berguna dalam hal mengidealkan kualitas jaringan. Search algorithm atau algoritma pencarian menggunakan konsep iterasi. Setiap iterasi terdiri dari satu parameter perubahan pada salah satu sektor. Algoritma pencarian termasuk fase tuning antara pencarian dan menyortir fase sesuai dengan konfigurasi pengaturan ACP. Fase tuning digunakan untuk meningkatkan solusi terbaik yang ditemukan selama fase pencarian. Sorting algoritm akan menemukan perubahan yang terbaik untuk diterapkan dari beberapa perubahan yang tersedia. Perubahan tersebut menjadi salah satu fungsi untuk meningkatkan kualitas jaringan (Forsk, 2015). Proses Optimasi ACP dapat ditunjukkan pada Gambar 2.

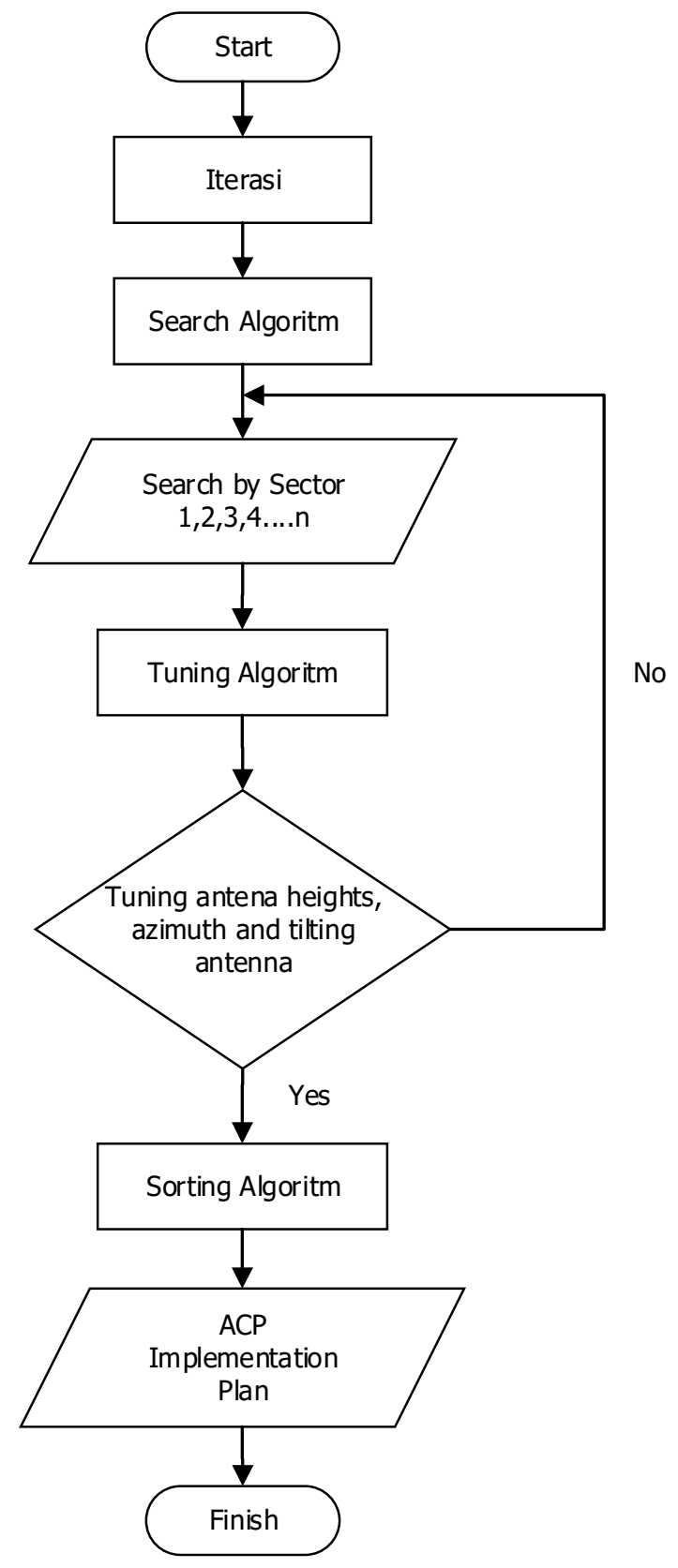

Gambar 2. Diagram Alir Algoritma ACP (Forsk, 2015) 


\subsection{Parameter Simulasi}

Untuk mengamati kualitas jaringan LTE dapat digunakan dengan coverage prediction. Terdapat beberapa prediksi yang dapat digunakan untuk mengamati kualitas jaringan LTE. Pada penelitian ini menggunakan prediksi Effective Signal Analysis dan Coverage by $C /(I+N)$ Level. Prediksi tersebut berhubungan dengan prediksi yang ada di ACP untuk menentukan parameter nilai RSRP dan CINR setelah proses optimasi physical tuning menggunakan metode ACP.

\section{Reference Signal Received Power (RSRP)}

Prediksi Effective Signal Analysis digunakan untuk mengamati parameter RSRP pada simulasi software Atoll. Reference Signal Received Power (RSRP) pada LTE digunakan untuk mengetahui nilai poweryag diterima pada sisi eNodeB ke User Equipment (UE).

Tabel 4. Range Nilai RSRP (Fadlan, 2014)

\begin{tabular}{|c|c|}
\hline Range Nilai RSRP (dBm) & Indikator \\
\hline$-80 \leq \mathrm{x}$ & Sangat Baik \\
\hline$-95 \leq \mathrm{x} \leq-80$ & Baik \\
\hline$-110 \leq \mathrm{x} \leq-95$ & Normal \\
\hline $\mathrm{x} \leq-110$ & Buruk \\
\hline
\end{tabular}

2. CINR Carrier to Interference Noise Ratio (CINR)

Prediksi Coverage by $C(I+N)$ level dapat digunakan untuk mengamati beberapa parameter salah satunya ialah parameter Carrier to Interference Noise Ratio (CINR). CINR merupakan perbandingan antara sinyal informasi dengan interferensi atau noise yang menyertainya.

Tabel 5. Range Nilai CINR (Fadlan, 2014)

\begin{tabular}{|c|c|}
\hline Range Nilai CINR (dB) & Indikator \\
\hline $20 \leq \mathrm{x}$ & Sangat Baik \\
\hline $13 \leq \mathrm{x} \leq 20$ & Baik \\
\hline $0 \leq \mathrm{x} \leq 13$ & Normal \\
\hline $\mathrm{x} \leq 0$ & Buruk \\
\hline
\end{tabular}

\section{HASIL DAN PEMBAHASAN}

\subsection{Analisis Hasil Simulasi Site Existing}

Simulasi site existing merupakan kondisi awal jaringan LTE sebelum dilakukan optimasi physical tuning antena menggunakan metode ACP. Physical tuning antena yang meliputi parameter tinggi antena, azimuth dan tilting antena sektoral. Kondisi site existing di Purwokerto Barat dan Utara memiliki 15 site dengan jumlah sector sebanyak 66 sector. Prediksi yang digunakan untuk mngetahui distribusi sinyal dari RSRP meggunakan prediksi coverage by effective signal analysis dan untuk mengetahui distribusi sinyal dari CINR menggunakan prediksi coverage by $C(I+N)$ level. Kualitas penyebaran sinyal hasil simulasi site existing dengan propagasi COST-231 Hata yang ditampilkan pada Gambar 3 dan Gambar 4. 


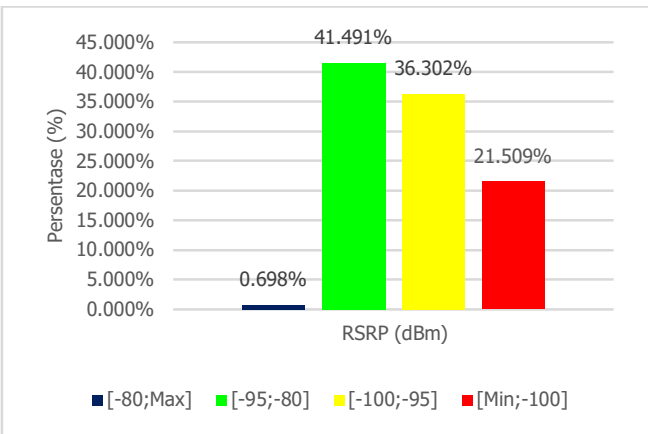

\section{Gambar 3. Histogram Nilai RSRP Site Existing}

Pada Gambar 3 perolehan hasil simulasi site existing nilai RSRP belum memenuhi standar KPI Operator yaitu sebesar $80 \% \geq(100) \mathrm{dBm}$ karena hanya memperoleh $78,491 \% \geq(100) \mathrm{dBm}$

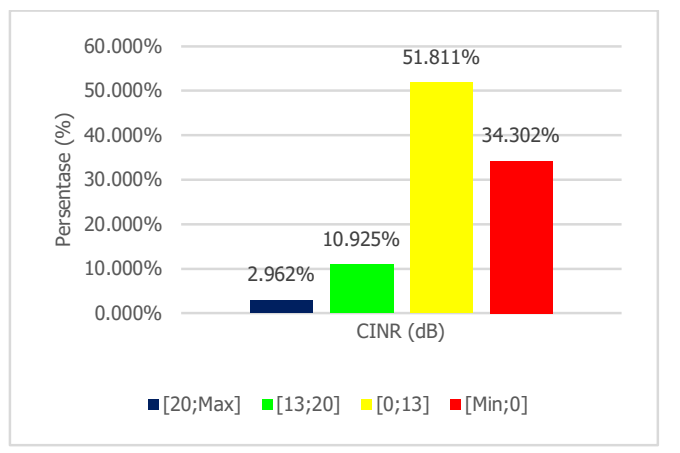

\section{Gambar 4. Histogram Nilai CINR Site Existing}

Pada Gambar 4 perolehan hasil simulasi site existing nilai CINR belum memenuhi standar KPI Operator yaitu sebesar $90 \% \geq(0) \mathrm{dB}$ karena hanya memperoleh $65,698 \% \geq(0) \mathrm{dB}$.

\subsection{Analisis Optimasi Metode ACP}

Optimasi physical tuning antena menggunakan metode Automatic Cell Planning (ACP) secara coverage dengan mengalkulasi parameter optimasi physical tuning antena pada seluruh site existing berdasarkan cakupan yang telah ditentukan. Parameter physical tuning antena meliputi tinggi antena, azimuth dan tilting antena. Kalkulasi metode ACP menggunakan 3 algoritma yaitu algoritma pencarian, algoritma tuning dan algoritma sorting. Algoritma pencarian dan algoritma tuning digunakan untuk menemukan yang terbaik dari kombinasi parameter untuk mengidealkan target yang ditentukan. Algoritma sorting menyediakan suatu rencana implementasi perubahan mana yang paling berguna dalam hal mengidealkan target yang ditentukan.

Statistic optimasi pysical tuning antena menggunakan metode ACP digunakan untuk melihat persentase improvement berdasarkan parameter RSRP dan CINR. Perolehan nilai persentase RSRP dan CINR diperoleh dari besarnya tingkat keberhasilan distribusi sinyal yang berada di atas $-100 \mathrm{dBm}$ untuk RSRP dan $0 \mathrm{~dB}$ untuk CINR Statistics improvement hasil optimasi dengan metode ACP yang ditampilkan pada Tabel 6. 
Penerapan Metode ACP untuk Optimasi Physical Tuning Antena Sektoral pada Jaringan 4G LTE di Kota Purwokerto

Tabel 6. Statistic Objective RSRP dan CINR

\begin{tabular}{|c|c|c|}
\hline Parameter & Site existing & Optimasi ACP \\
\hline RSRP & $78,30 \%$ & $90,02 \%$ \\
\hline CINR & $66,82 \%$ & $95,56 \%$ \\
\hline
\end{tabular}

Nilai awal untuk parameter RSRP sebesar 78,30\% dan nilai akhir RSRP memperoleh persentase sebesar 90,02\%. Sehingga untuk parameter RSRP memperoleh improvement sebesar $11,72 \%$. Nilai awal untuk parameter CINR sebesar $66,82 \%$ dan nilai akhir CINR memperoleh persentase sebesar 95,56\%. Sehingga untuk parameter CINR memperoleh improvement sebesar $28,73 \%$. Dengan perolehan nilai statistics tersebut artinya optimasi physical tuning antena sektoral metode ACP berhasil mencapai target KPI Operator yang telah ditentukan.

Quality digunakan untuk mengetahui tingkat keberhasilan dan kegagalan hasil optimasi dengan metode ACP. Tingkat keberhasilan dan kegagalan optimasi dengan metode ACP berdasarkan threshold level sesuai dengan standar KPI Operator yang ditampilkan pada Gambar 5 dan Gambar 6.

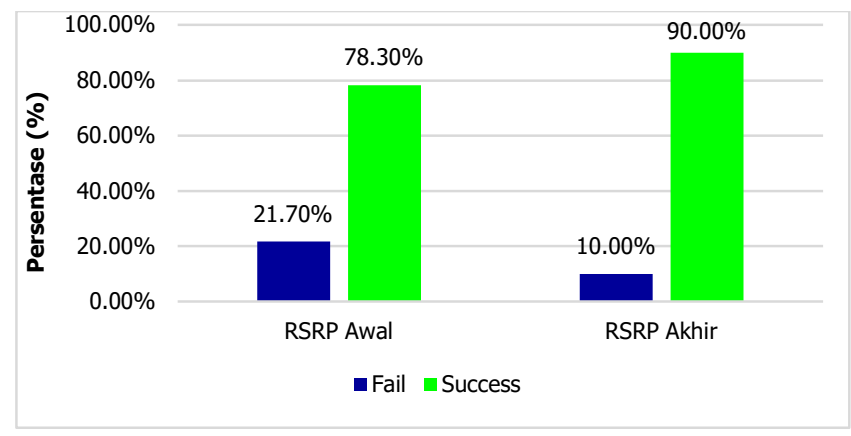

Gambar 5. Histogram Nilai Quality RSRP

Pada Gambar 5 digunakan untuk melihat hasil optimasi ACP dari paramater RSRP dan CINR secara coverage. Nilai awal merupakan kondisi awal sebelum dilakukan optimasi metode ACP atau sesuai dengan data site existing. Nilai akhir merupakan kondisi akhir setelah dilakukan optimasi metode ACP. Tingkat keberhasilan nilai RSRP secara coverage dengan threshold di atas $-100 \mathrm{dBm}$ mengalami peningkatan dari $78,3 \%$ menjadi $90 \%$ sedangkan tingkat kegagalan yang berada di bawah $-100 \mathrm{dBm}$ mengalami penurunan dari $21,7 \%$ menjadi $10 \%$. Selisih tingkat keberhasilan dan kegagalan nilai RSRP antara site existing dengan optimasi metode ACP sebesar $11,7 \%$.

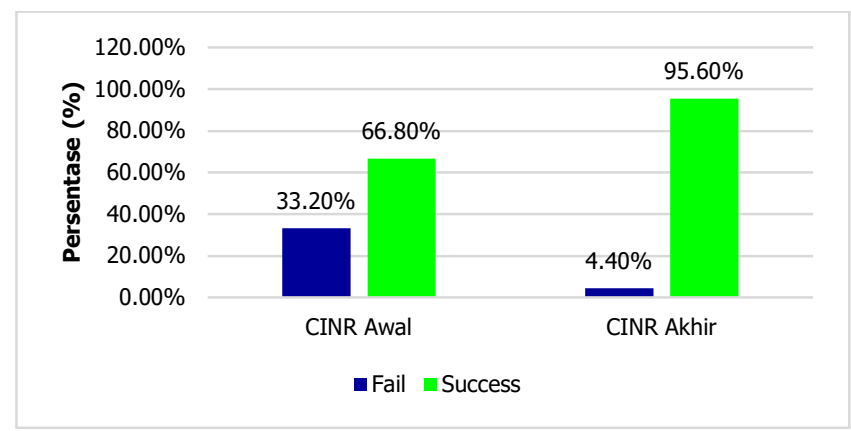

Gambar 6. Histogram Nilai Quality CINR 
Pada Gambar 6 digunakan untuk melihat hasil optimasi ACP dari paramater CINR secara coverage. Tingkat keberhasilan nilai CINR secara coverage dengan threshold di atas $0 \mathrm{~dB}$ mengalami peningkatan dari $66,80 \%$ menjadi $95,6 \%$ sedangkan tingkat kegagalan yang berada di bawah $0 \mathrm{~dB}$ mengalami penurunan dari 33,2\% menjadi 4,4\%. Selisih tingkat keberhasilan dan kegagalan nilai CINR antara site existing dengan optimasi metode ACP sebesar $28,8 \%$.

Untuk megetahui kualitas jaringan LTE setelah optimasi physical tuning antena sektoral menggunakan metode ACP berdasarkan parameter RSRP dan CINR dapat dilihat pada Gambar 7 dan Gambar 8.

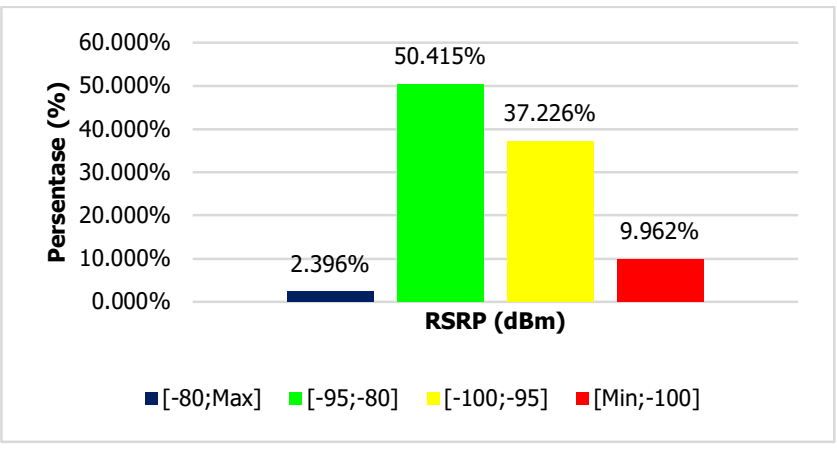

Gambar 7. Histogram Nilai RSRP Optimasi ACP

Pada Gambar 7 perolehan hasil simulasi optimasi physical tuning antena sektoral menggunakan metode ACP nilai persentase RSRP secara coverage sudah memenuhi standar KPI operator telekomunikasi yaitu sebesar $90,037 \% \geq(100) \mathrm{dBm}$ dengan target yang ditentukan yaitu $80 \% \geq(100) \mathrm{dBm}$.

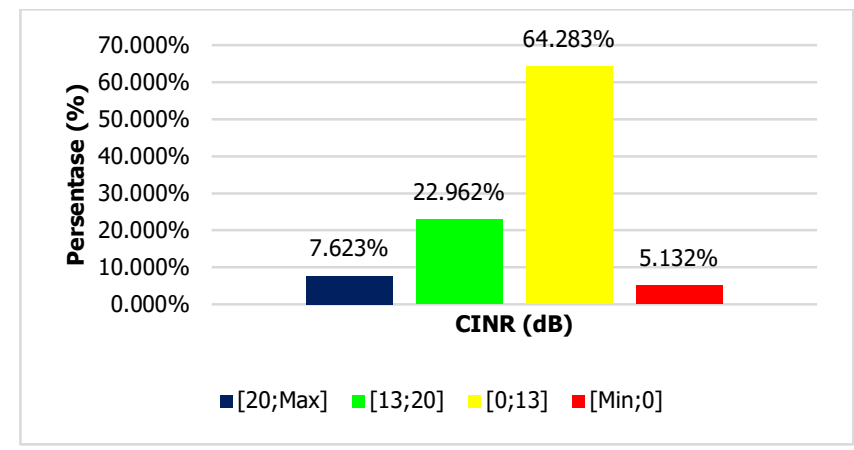

Gambar 8. Histogram Nilai CINR Optimasi ACP

Pada Gambar 8 perolehan hasil simulasi optimasi physical tuning antena sektoral menggunakan metode ACP nilai persentase CINR secara coverage sudah memenuhi standar KPI Operator yaitu sebesar $94,868 \% \geq(0)$ dB dengan target yang ditentukan yaitu $90 \% \geq$ (0) $\mathrm{dB}$.

\subsection{Analisis Perbandingan Hasil Simulasi Site Existing dengan Hasil Optimasi Metode ACP}

Perbandingan dilakukan berdasarkan perolehan penyebaran sinyal kondisi site existing dengan hasil optimasi physical tuning antena sektoral menggunakan metode ACP melalui simulasi coverage prediction pada software Atoll. Parameter yang dibandingkan yaitu RSRP dan CINR. Hasil analisis perbandingan parameter RSRP dan CINR dari site existing dengan 
hasil optimasi physical tuning antena sektoral menggunakan metode ACP yang ditampilkan pada Gambar 9 dan Gambar 10.

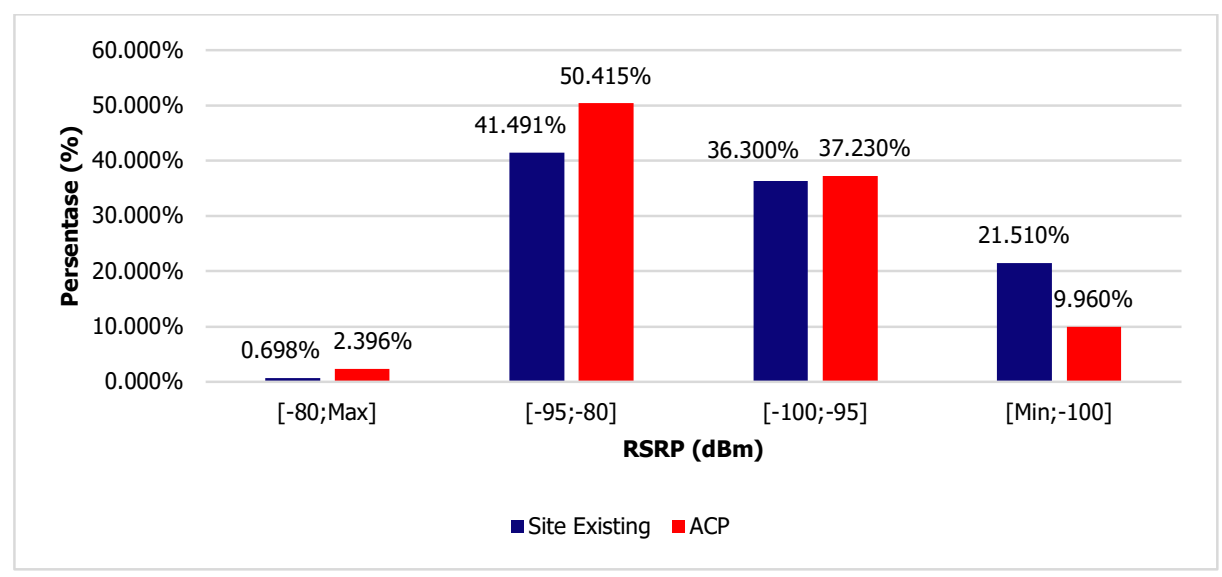

Gambar 9. Perbandingan Nilai RSRP

Pada Gambar 9 hasil optimasi physical tuning antena menggunakan metode ACP pada range di atas $-80 \mathrm{dBm}$ mendapatkan selisih sebesar 1,698\% dengan hasil simulasi site existing. Nilai RSRP hasil optimasi ACP pada range $-95 \mathrm{dBm}$ hingga $-80 \mathrm{dBm}$ mengalami peningakatan yang lebih baik dengan selisih sebesar $8,924 \%$ dengan simulasi site existing. Nilai RSRP hasil optimasi ACP pada range $-100 \mathrm{dBm}$ hingga $-95 \mathrm{dBm}$ mendapatkan selisih sebesar $0,924 \%$ dengan simulasi site existing. Nilai RSRP hasil optimasi ACP pada range di bawah $-100 \mathrm{dBm}$ mengalami penurunan selisih sebesar $11,547 \%$ dengan simulasi site existing. Perbandingan persentase nilai RSRP hasil optimasi metode ACP pada range di atas $-100 \mathrm{dBm}$ sesuai dengan standar KPI operator telekomunikasi sebesar 90,037\% dan nilai RSRP hasil simulasi site existing sebesar $78,491 \%$.

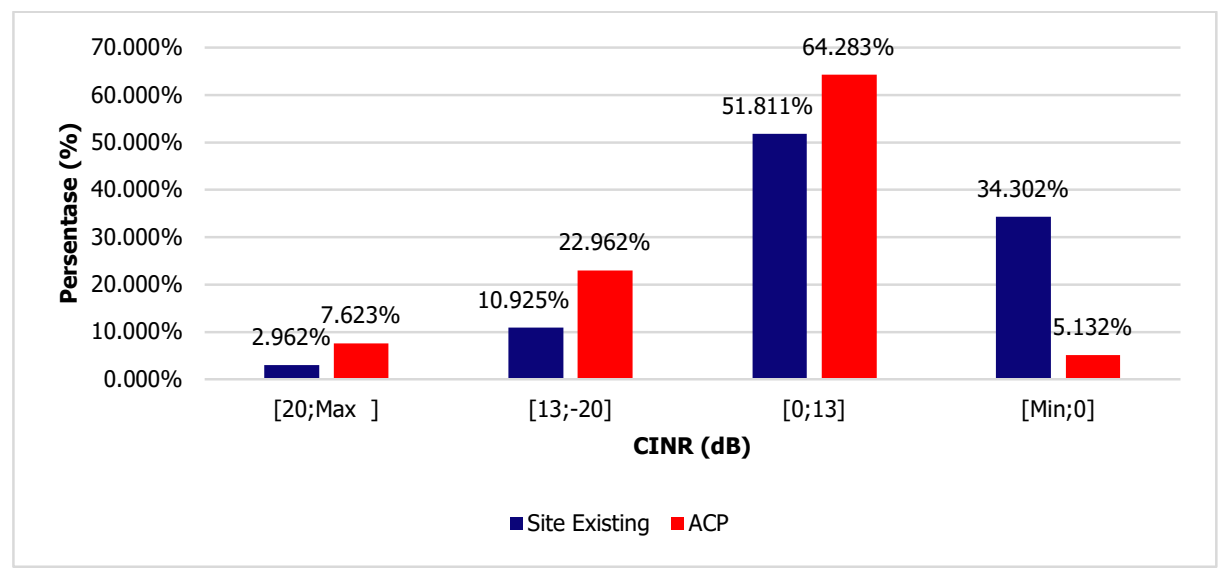

Gambar 10. Perbandingan Nilai CINR

Pada Gambar 10 hasil optimasi physical tuning antena menggunakan metode ACP pada range di atas $20 \mathrm{~dB}$ mendapatkan selisih sebesar 4,661\% dengan hasil simulasi site existing. Nilai CINR hasil optimasi ACP pada range $13 \mathrm{~dB}$ hingga $20 \mathrm{~dB}$ mendapatkan selisih sebesar $12,037 \%$ dengan simulasi site existing. Nilai CINR hasil optimasi ACP pada range $0 \mathrm{~dB}$ hingga $13 \mathrm{~dB}$ mengalami peningkatan yang signifikan dengan selisih sebesar $12,472 \%$ dengan simulasi site existing. Nilai CINR hasil optimasi ACP pada range di bawah $0 \mathrm{~dB}$ mengalami 
Purnama, dkk

penurunan selisih sebesar $29,17 \%$ dengan simulasi site existing. Perbandingan persentase nilai CINR hasil optimasi metode ACP pada range di atas $0 \mathrm{~dB}$ sesuai dengan standar KPI operator telekomunikasi sebesar $94,868 \%$ dan nilai CINR hasil simulasi site existing sebesar $65,698 \%$.

\section{KESIMPULAN}

Kesimpulan yang diperoleh dari hasil simulasi penelitian ini tentang optimasi physical tuning antena sektoral menggunakan metode Automatic Cell Planning (ACP) sebagai berikut :

1. Hasil simulasi site existing nilai persentase tingkat keberhasilan RSRP pada threshold di atas $-100 \mathrm{dBm}$ memperoleh $78,30 \%$ dan nilai persentase CINR pada threshold di atas 0 dB memperoleh $66,80 \%$, sedangkan tingkat kegagalan RSRP pada threshold di bawah -100 dBm memperoleh $21,70 \%$ dan nilai persentase CINR pada threshold di bawah $0 \mathrm{~dB}$ memperoleh $33,20 \%$

2. Hasil simulasi optimasi physical tuning antena sektoral menggunakan metode ACP nilai persentase tingkat keberhasilan RSRP pada threshold di atas $-100 \mathrm{dBm}$ memperoleh $90 \%$ dan nilai persentase CINR pada threshold di atas $0 \mathrm{~dB}$ memperoleh $95,60 \%$ sedangkan tingkat kegagalan RSRP pada threshold diatas $-100 \mathrm{dBm}$ memperoleh $10 \%$ dan nilai persentase CINR pada threshold di bawah $0 \mathrm{~dB}$ memperoleh 4,40\%.

3. Perolehan persentse tingkat keberhasilan distribusi sinyal parameter RSRP sudah memenuhi standar KPI Operator sebesar $90 \%$ dengan tingkat kegagalan distribusi sinyal sebesar 10\%. Tingkat keberhasilan parameter CINR sudah memenuhi standar KPI Operator sebesar $95,60 \%$ dengan tingkat kegagalan distribusi sinyal sebesar 4,40\%.

4. Hasil simulasi site existing perolehan nilai persentase RSRP dan CINR secara coverage belum memenuhi standar KPI Operator yaitu sebesar $78,491 \% \geq(-100) \mathrm{dBm}$ untuk RSRP dan $65,698 \% \geq(0)$ dB untuk CINR.

5. Hasil simulasi optimasi physical tuning antena sektoral menggunakan metode ACP secara coverage sudah memenuhi standar KPI Operator yaitu sebesar $90,037 \% \geq(-100)$ $\mathrm{dBm}$ untuk RSRP dan $94,868 \% \geq(0) \mathrm{dB}$ untuk CINR.

6. Kualitas penyebaran sinyal parameter RSRP dan CINR yang didapatkan setelah optimasi physical tuning antena sektoral menggunakan metode ACP mengalami peningkatan dilihat dari hasil improvement sebesar 11,72\% untuk RSRP dan $28,73 \%$ untuk CINR.

\section{UCAPAN TERIMA KASIH}

Terimakasih penulis ucapkan kepada PT. Telkomsel Purwokerto, Bapak Eka Setia Nugraha, Bapak Muntaqo Alfin Amanaf dan Bapak Rafi yang sudah membantu penulis dalam mengerjakan jurnal ini.

\section{DAFTAR RUJUKAN}

Banyumas, B. P. (2018). Kecamatan Purwokerto Dalam Angka 2018. Banyumas: Badan Pusat Statistik Kabupaten Banyumas.

Fadlan, A. (2014). Report DT Protelindo Project Telkomsel Inner Banjarmasin.

Forsk. (2010). Atoll RF Planning \& Optimisation Software. Forsk. 
Penerapan Metode ACP untuk Optimasi Physical Tuning Antena Sektoral pada Jaringan 4G LTE di Kota Purwokerto

Forsk. (2015). Atoll 3.3.0 Technical Reference Guide For Radio Network. Blagnac.

Ginting, M. B. (2017). Optimasi Jaringan Coverage UMTS Dengan Azimuth Dan Tilting Antena Sektoral. Purwokerto: Institut Teknologi Telkom Purwokerto.

Hikmaturokhman, A., Wardhana, L., \& Mahardika, G. (2014). 4G Handbook Edisi Bahasa Indonesia Jilid 2. Jakarta: www.nulisbuku.com.

Huawei. (2013, Juli 15). Model: ADU451816v01 Electrical Properties. Shenzhen: Huawei Technologies. Diambil kembali dari Scribd: https://www.scribd.com/doc/205076946/ADU451816v01

Motorolla. (2011). LTE RF Planning Guide.

Putra, I. D., Widhi, P. R., \& Ifur, A. G. (2017). 4 G LTE Advanced For Beginner \& Consultant. Depok: Prandia Self.

Telkomsel. (2016). Daily LTE Performance. Jakarta: Telkomsel.

Wibawa, F. P. (2019). Perencanaan Dan Analisis Fronthaul Microwave Menggunakan Spektrum Frekuensi $71 \mathrm{GHz}$ Untuk Radio Access Network Dengan Menggunakan Metode Drive Test 4G LTE Di Kota Purwokerto. Purwokerto: Institut Teknologi Telkom Purwokerto. 